\title{
Fractionation and characterization of cystine aminopeptidase (oxytocinase) and arylamidase of human serum during pregnancy
}

\author{
Saara Lampelo and T. Vanha-Perttula \\ Department of Anatomy, University of Kuopio, P.O. Box 138, 70101 Kuopio 10, Finland
}

\begin{abstract}
Summary. Cystine aminopeptidase and arylamidase activities in human serum were determined by enzymic hydrolysis of L-cystine-di- $\beta$-naphthylamide (CysNA) and Lleucine- $\beta$-naphthylamide (LeuNA), respectively. The activities of both enzymes increased during pregnancy, cystine aminopeptidase $12 \cdot 5$-fold and arylamidase $8 \cdot 3$ fold.
\end{abstract}

Serum CysNA and LeuNA hydrolysing aminopeptidases were separated by gel filtration on Sepharose 6B. Serum from non-pregnant women (control) contained arylamidase $\left(I_{c}\right)$, which hydrolysed LeuNA and (weakly) CysNA, and cystine aminopeptidase II, hydrolysing only CysNA. During pregnancy a new enzyme appeared in maternal serum and showed cystine aminopeptidase and arylamidase activity $\left(\mathrm{I}_{m}\right)$. Maternal serum Enzyme(s) I had higher pH optima (6.5 with CysNA; 7.5 with LeuNA) and higher molecular weights $(309000)$ than arylamidase $I_{c}(p H$ optima at 5.52-5.5 with CysNA and 7.0 with LeuNA; mol.wt $\sim 130000$ ). Arylamidase $I_{c}$ was more sensitive to $\mathrm{L}$-methionine, but more resistant to heat than maternal serum Enzyme(s) I. Both control and maternal serum Enzyme(s) I were inhibited by EDTA, but were re-activated by $\mathrm{Zn}^{2+}$ and $\mathrm{Co}^{2+}$ with LeuNA and $\mathrm{CysNA}$ as substrates and by $\mathrm{Ni}^{2+}$ with CysNA. Cystine aminopeptidase $\mathrm{I}_{m}$ and arylamidase $\mathrm{I}_{\mathrm{m}}$ may be a single enzyme although differences were obtained in $\mathrm{pH}$ optima and reactivation by $\mathrm{Ni}^{2+}$ after EDTA treatment. Since maternal serum Enzyme(s) I had biochemical characteristics similar to those of placental aminopeptidase(s) I, it is suggested that the activities are of placental origin. Cystine aminopeptidase II appeared in all sera. It differed clearly from both maternal and control serum Enzyme(s) I: it had the lowest molecular weight $(76000)$, a different $\mathrm{pH}$ optimum $(6 \cdot 0)$, and was resistant to EDTA and L-methionine. It was not as effectively inhibited by $\mathrm{Ni}^{2+}$ as was Enzyme(s) I.

\section{Introduction}

During pregnancy an aminopeptidase that is able to inactivate oxytocin and vasopressin appears in the maternal serum (von Fekete, 1930; Stoklaska \& Wintersberger, 1959). The enzyme, originally named oxytocinase, disappears rapidly after parturition and has been suggested to play an important role in the maintenance and termination of a normal pregnancy (Gazarek et al., 1976). However, the physiological importance of serum oxytocinase has been questioned because oxytocin is rapidly removed from the circulation by the liver and kidneys.

Oxytocinase and cystine aminopeptidase (EC 3.4.11.3) are considered to be the same enzyme (Tuppy \& Nesvadba, 1957; Melander, 1965). Cystine aminopeptidase levels show a progressive rise throughout normal pregnancy, reaching a maximum in the last trimester (Babuna \& Yenen, 1966; Gazarek et al., 1976). The enzyme is present in high concentration in 
the placental tissue (Lampelo \& Vanha-Perttula, 1979) and the cystine aminopeptidase (oxytocinase) activity determined in the serum of pregnant women with oxytocin or various synthetic substrates (among these L-cystine-di- $\beta$-naphthylamide and L-leucine- $\beta$-naphthylamide) may be of placental origin (Oya, Yoshino, Mizutani \& Wakabayashi, 1974). The enzyme concentration in maternal serum is supposed to reflect the increased activity of the placental tissue (Spellacy, Usategui-Gomez \& Fernandez-deCastro, 1977).

Normal serum contains several aminopeptidases (Kulling \& Yman, 1970). The activity of an arylamidase which hydrolyses L-leucine- $\beta$-naphthylamide has been known to increase during pregnancy and has been considered to be at least partly due to the appearance of cystine aminopeptidase (oxytocinase), which shows a broad substrate specificity (Kulling \& Yman, 1970).

This report is concerned with the fractionation of sera from pregnant and non-pregnant women by gel filtration and the biochemical characterization of the enzyme activities with $\mathbf{L}$ cystine-di- $\beta$-naphthylamide and L-leucine- $\beta$-naphthylamide as substrates.

\section{Materials and Methods}

\section{Blood samples}

Maternal blood samples were taken from the brachial vein at 38-41 weeks of pregnancy. The women were healthy and had no complications of pregnancy and in each case there was normal fetal growth. Serum samples from non-pregnant women were used as controls. The women had not used any oral contraceptives. The sera were separated after clotting by centrifugation at $600 \mathrm{~g}$ for $10 \mathrm{~min}$, at $+4^{\circ} \mathrm{C}$.

\section{Reagents}

All reagents were obtained as indicated by Lampelo \& Vanha-Perttula (1979).

\section{Gel filtration}

Gel filtration by Sepharose 6B was carried out as described earlier (Lampelo \& VanhaPerttula, 1979). The gel bed was equilibrated and the serum samples of $5 \mathrm{ml}$ were eluted with $0.02 \mathrm{M}$-Tris- $\mathrm{HCl}$ buffer, $\mathrm{pH} 7 \cdot 0$. The buffer contained $0.15 \mathrm{M}-\mathrm{NaCl}$. Fractions of $10 \mathrm{ml}$ were collected at $+4^{\circ} \mathrm{C}$.

\section{Measurement of the enzyme activity}

The hydrolysis of L-cystine-di- $\beta$-naphthylamide (CysNA) and L-leucine- $\beta$-naphthylamide (LeuNA) was determined as described by Lampelo \& Vanha-Perttula (1979). The incubation medium contained $0.3 \mathrm{ml} 0.1 \mathrm{M}$-Tris- $\mathrm{HCl}$ buffer, $\mathrm{pH} 7.0$ (unless otherwise indicated), $0.1 \mathrm{ml}$ enzyme solution and $0.1 \mathrm{ml}$ substrate solution at a final concentration of $0.25 \mathrm{mM}$. After incubation at $37^{\circ} \mathrm{C}$ the liberated $\beta$-naphthylamine was coupled with $0.2 \mathrm{ml}$ of Fast Garnet GBC in $1 \mathrm{M}$-acetate buffer, $\mathrm{pH} 4 \cdot 2$, to which $10 \%$ Tween was added to disperse the colour product. The absorbancies were read spectrophotometrically at a wavelength of $525 \mathrm{~nm}$. The aminopeptidase activities of total sera (unfractionated sera) are given as $\mu \mathrm{mol} \beta$-naphthylamine liberated $/ \mathrm{min} / \mathrm{mg}$ protein. All the assays were in duplicate or triplicate and in the studies of enzyme characteristics a duplicate control from the same sample was always included. The protein concentrations of total serum samples were estimated according to Lowry, Rosebrough, Farr \& Randall (1951). The protein concentration of the chromatographic fractions was monitored by their absorbance at $280 \mathrm{~nm}$. 


\section{Studies on enzyme characteristics}

The $\mathrm{pH}$ optima, thermal sensitivities and molecular weights were determined for the pooled enzyme preparations and the effects of various modifiers were tested as described by Lampelo \& Vanha-Perttula (1979). The $\mathrm{pH}$ optima for the different enzymes separated by Sepharose 6B gel filtration were determined in a series of phosphate buffers $(1 / 15 \mathrm{M})$ having a $\mathrm{pH}$ range between 5 and 8 . Various modifier substances were dissolved in $0.1 \mathrm{M}$-Tris- $\mathrm{HCl}$ buffer, $\mathrm{pH} 7.0$, and these solutions were used as reagent controls in the assays. The effect of different buffers on the response to EDTA $(0.75 \mathrm{mM})$ was studied in Tris- $\mathrm{HCl}$, phosphate and dimethyl glutaric acid buffers with rising molarities at $\mathrm{pH} 7 \cdot 0$. The molecular weights were measured according to Whitaker's principle (1963), in which the reference proteins were $\gamma$-globulin (mol.wt 165000 ). bovine serum albumin (mol.wt 67000 ) and cytochrome c (mol.wt 12400 ).

\section{Statistical analysis}

Means and standard errors (s.e.m.) were calculated and the significance of the differences was determined by Student's $t$ test.

\section{Results}

\section{Aminopeptidase activities of total serum}

Total cystine aminopeptidase and arylamidase activities were significantly higher in maternal serum than in control serum $(P<0.001)$ (Table 1). In both sera CysNA was hydrolysed more slowly than LeuNA. However, during pregnancy cystine aminopeptidase activity increased 12.5-fold and arylamidase activity 8.3-fold compared to the activities in control sera (Table 1).

Table 1. Total cystine aminopeptidase (CysNA) and arylamidase (LeuNA) activities of control and maternal

sera

\begin{tabular}{lll}
\hline \multicolumn{1}{c}{ Sample } & \multicolumn{1}{c}{$\begin{array}{c}\text { Cystine } \\
\text { aminopeptidase }\end{array}$} & \multicolumn{1}{c}{ Arylamidase } \\
\hline Control sera (C) & $0.02 \pm 0.001(7)$ & $0.46 \pm 0.06(7)$ \\
Maternal sera (M) & $0.25 \pm 0.01(8)$ & $3.82 \pm 0.25(8)$ \\
M:C & 12.5 & 8.3 \\
\hline
\end{tabular}

Values are mean \pm s.e.m. for the no. of triplicate experiments indicated in parentheses, and are given as $\mu \mathrm{mol} \beta$ naphthylamine liberated $/ \mathrm{min} / \mathrm{mg}$ protein.

\section{Gel filtration}

One enzyme activity peak hydrolysing LeuNA and eluting in Fractions 29-31 was separated from control serum by Sepharose 6B fractionation (Text-fig. 1). This enzyme also hydrolysed CysNA weakly and was called control serum arylamidase $I$ (arylamidase $I_{c}$ ). With CysNA as substrate, a second enzyme activity was separated, eluting in Fractions 33-37. This activity peak, hydrolysing only CysNA, was called cystine aminopeptidase II (Text-fig. 1).

Fractionation of the maternal serum on Sepharose 6B showed that a new enzyme appeared in the serum during pregnancy. It was detected with both substrates in Fractions 23-28 and was called maternal serum arylamidase (arylamidase $I_{m}$ ) when LeuNA was used as substrate and maternal serum cystine aminopeptidase I (cystine aminopeptidase $I_{m}$ ) with CysNA as substrate. The last fractions of this first activity peak of maternal serum were overlapped by the weaker activity of arylamidase I. This was more apparent with LeuNA as substrate and gave a tailing to the peak. The maternal serum also had a separate activity, cystine aminopeptidase II, 


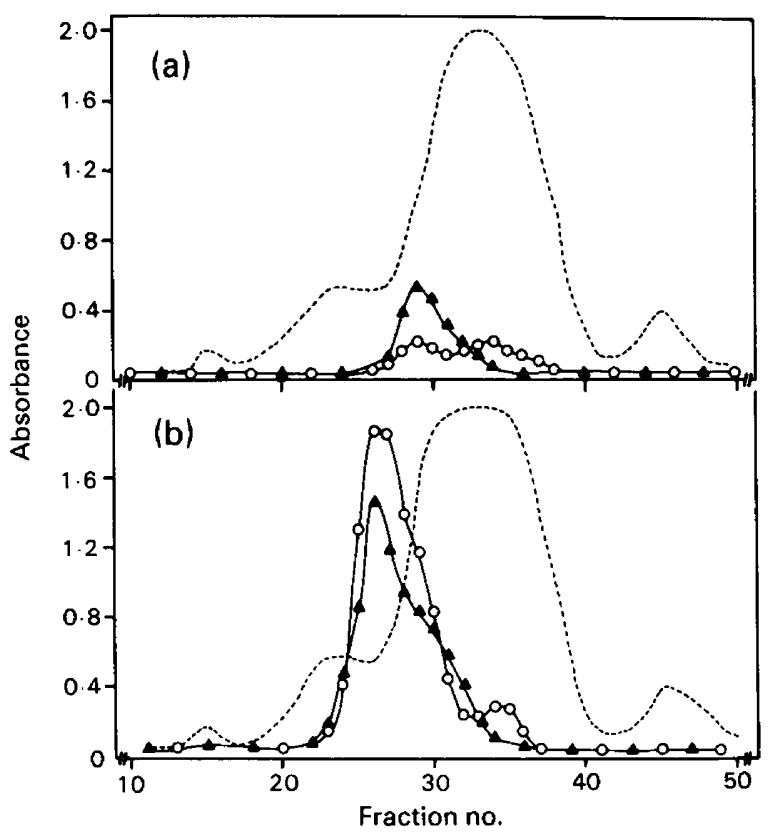

Text-fig. 1. Elution patterns of enzymes hydrolysing CysNA (O) and LeuNA (A) after Sepharose 6B gel filtration of (a) control serum and (b) maternal serum of women. Incubation time was $1 \mathrm{~h}$ (control serum) or $30 \mathrm{~min}$ (maternal serum) with LeuNA and $7 \mathrm{~h}$ (control and maternal serum) with CysNA. The protein content of the $10-\mathrm{ml}$ fractions is given as the absorbance at $280 \mathrm{~nm}(---)$.

hydrolysing only CysNA. This eluted in coincident fractions with a similar activity of the control serum.

\section{Studies on enzyme characteristics}

Three pooled enzyme preparations were utilized: Fractions $23-28$ and 33-37 of the gel filtration of maternal serum formed enzyme samples $I_{m}$ and $I I$, respectively. Enzyme sample $I_{c}$ was obtained by pooling Fractions 29-31 after gel filtration of control serum.

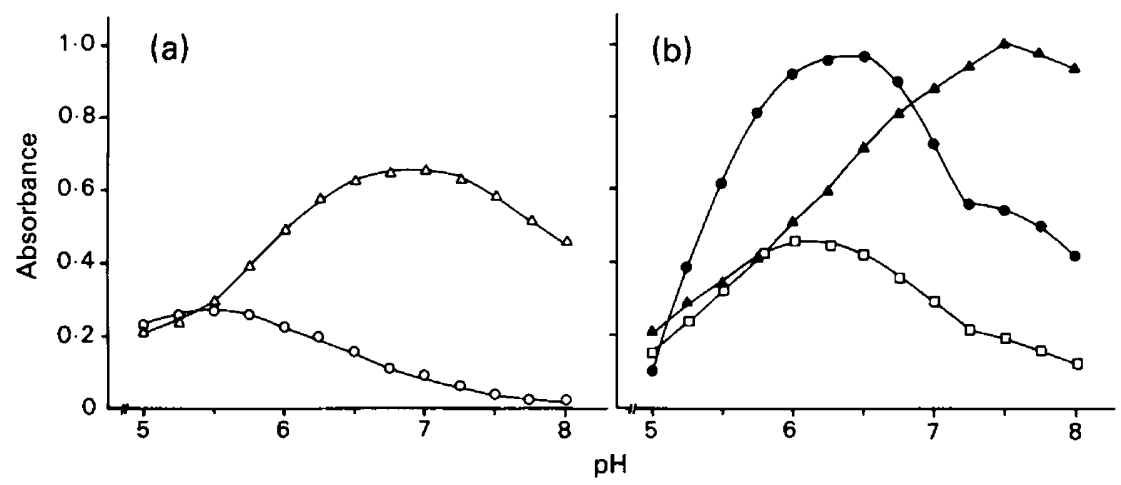

Text-fig. 2. Effect of pH on the hydrolysis of CysNA and LeuNA by the pooled samples of (a) control and (b) maternal serum enzymes separated by gel filtration. Five separate anlyses were carried out and the tracings give representative patterns for arylamidase $I_{c}$ with LeuNA $(\triangle)$ and with CysNA (O); cystine aminopeptidase $\mathrm{I}_{\mathrm{m}}(\mathrm{O})$; cystine aminopeptidase II ( $\square$ ); and arylamidase $I_{m}(\Delta)$. 
Enzyme II separated from control and maternal sera had similar properties and only the results with maternal serum preparation II are indicated in the tables and text-figures.

Optimal $p H$. The pooled preparation $I_{c}$ hydrolysed LeuNA optimally at about 7.0 and CysNA at pH 5.25-5.5 (Text-fig. 2a). Enzyme sample $I_{m}$ had an optimum at about $\mathrm{pH} 6.5$ for CysNA and at about pH 7.5 for LeuNA (Text-fig. 2b). Enzyme preparation II separated from maternal (Text-fig. 2b) and control sera hydrolysed CysNA optimally at $\mathrm{pH} 6.0$.

The effect of modifiers. Cystine aminopeptidase $I_{m}$, arylamidase $I_{m}$ and arylamidase $I_{c}$ were nearly totally inhibited by as low a concentration of the chelating agent EDTA as $0.001 \mathrm{~mm}$, whereas cystine aminopeptidase II was not inhibited (Text-fig. 3). Tests with other chelating agents, 2,2'-dipyridyl (Text-fig. 3), EGTA and 1,10-phenanthroline chloride, showed no differences in activity with arylamidase $I_{c}$, cystine aminopeptidase $I_{m}$, arylamidase $I_{m}$ and cystine aminopeptidase II.

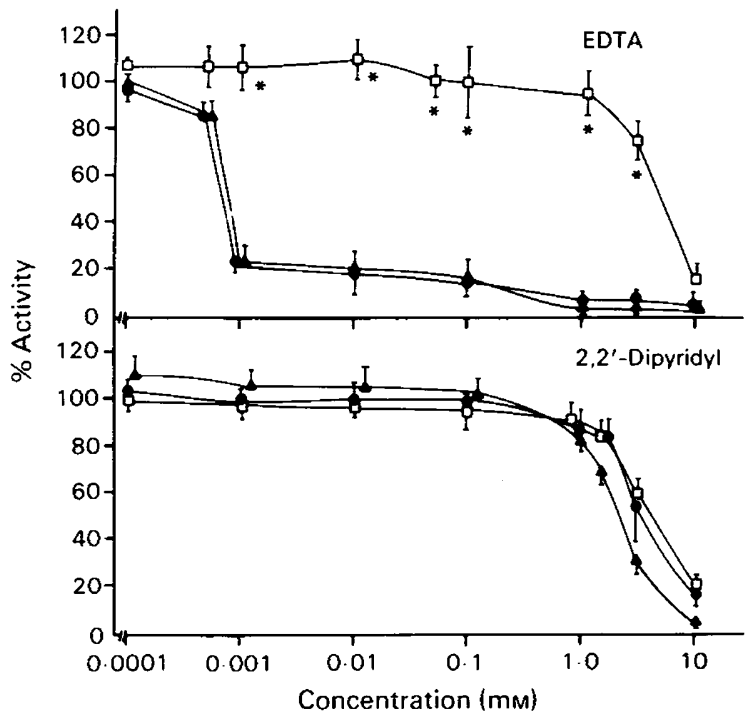

Text-fig. 3. Effect of various EDTA and 2,2'-dipyridyl concentrations on the hydrolysis of CysNA and LeuNA by the enzyme preparations, cystine aminopeptidase $I_{m}(\bullet)$; cystine aminopeptidase II ( $\square$ ) and arylamidase $I_{m}(\Delta)$. The results of 5 duplicate experiments are given as percentages $( \pm$ s.e.m.) of the appropriate duplicate controls $(100 \%)$. Values marked with an asterisk differ significantly $(P<0.001)$ from those of the other 2 enzymes.

The effect of the preincubation time on the enzyme activities was studied with EDTA at 0.75 mM concentration (Table 2). The inhibition of cystine aminopeptidase $I_{m}$, arylamidase $I_{m}$ and arylamidase $I_{c}$ (data not shown) took place gradually at the same pace, but the activity of cystine animopeptidase II remained stable, even with prolonged preincubation.

Cystine aminopeptidase II was inhibited by EDTA when phosphate buffer was used, noticeably at the high buffer molarities, but not by EDTA $(0.75 \mathrm{~mm})$ in Tris-HCl or dimethyl glutaric acid buffer (Text-fig. 4). Cystine aminopeptidase $I_{m}$ (Text-fig. 4), arylamidase $I_{m}$ and arylamidase $I_{c}$ were strongly inhibited by EDTA in all buffers used.

When the effect of various concentrations of divalent metal ions on the enzymes after EDTA pretreatment was studied (Text-fig. 5), $\mathrm{Co}^{2+}$ and $\mathrm{Zn}^{2+}$ re-activated cystine aminopeptidase $\mathrm{I}_{\mathrm{m}}$, arylamidase $I_{m}$ and arylamidase $I_{c}$ (data not shown) at concentrations equimolar with EDTA. At higher concentrations $\mathrm{Zn}^{2+}$ was inhibitory, whereas $\mathrm{Co}^{2+}$ retained the enzyme activities. Cystine aminopeptidase $I_{m}$ and arylamidase $I_{c}$ were also re-activated by $\mathrm{Ni}^{2+}$, but only when CysNA was used as substrate. $\mathrm{Mn}^{2+}$ gave partial re-activation (about $40 \%$ ), but $\mathrm{Ca}^{2+}$ and $\mathrm{Mg}^{2+}$ 
Table 2. The effect of preincubation time with EDTA $(0.75 \mathrm{mM})$ on the hydrolysis rate of LeuNA by the pooled arylamidase $I_{m}$ and of CysNA by the pooled cystine aminopeptidase $I_{m}$ and cystine aminopeptidase II

\begin{tabular}{cccc}
\hline $\begin{array}{c}\text { Preincubation } \\
\text { time (min) }\end{array}$ & ${\text { LeuNA } \mathrm{I}_{\mathrm{m}}}$ & CysNA I $_{\mathrm{m}}$ & CysNA II \\
\hline 15 & $35 \pm 6.8$ & $28 \pm 6.5$ & $85 \pm 10.2$ \\
30 & $31 \pm 6.9$ & $22 \pm 4.2$ & $88 \pm 9.8$ \\
45 & $25 \pm 5.2$ & $17 \pm 3.0$ & $94 \pm 8.8$ \\
60 & $23 \pm 4.2$ & $15 \pm 2.0$ & $96 \pm 13.1$ \\
75 & $19 \pm 3.3$ & $12 \pm 2.2$ & $94 \pm 12.5$ \\
90 & $13 \pm 4.9$ & $11 \pm 1.8$ & $91 \pm 10.7$ \\
105 & $10 \pm 4.6$ & $8 \pm 1.0$ & $92 \pm 12.0$ \\
120 & $10 \pm 4.1$ & $8 \pm 1.0$ & $91 \pm 12.5$ \\
\hline
\end{tabular}

The values are mean \pm s.e.m. percentages of the appropriate duplicate controls (100\%) for 3 duplicate experiments.

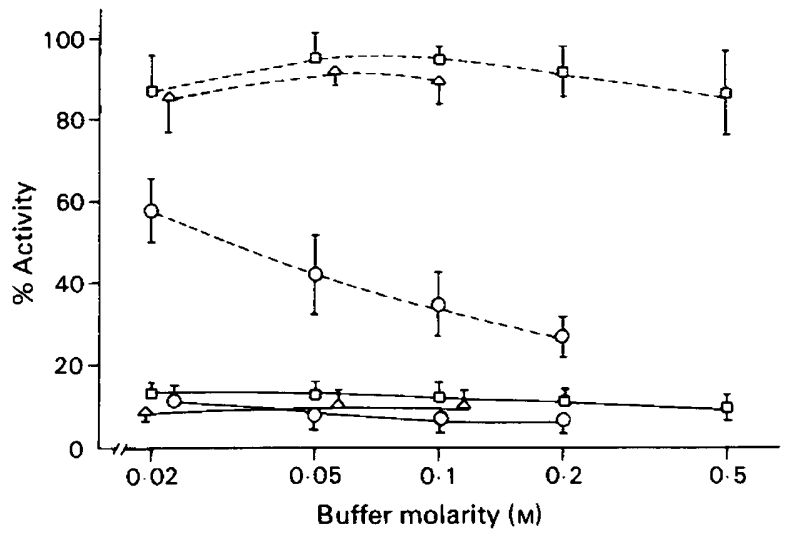

Text-fig. 4. Effect of $0.75 \mathrm{~mm}$-EDTA on the hydrolysis of CysNA by cystine aminopeptidase $\mathrm{I}_{\mathrm{m}}$ $(-)$ and II (--) from maternal serum. The molarities of the buffers (Tris-HCl, $\square$; phosphate, $O$; dimethyl glutaric acid, $\Delta$ ) are indicated as the initial concentrations. The results of 3 duplicate experiments are given as percentages $( \pm$ s.e.m.) of the appropriate duplicate controls $(100 \%)$.

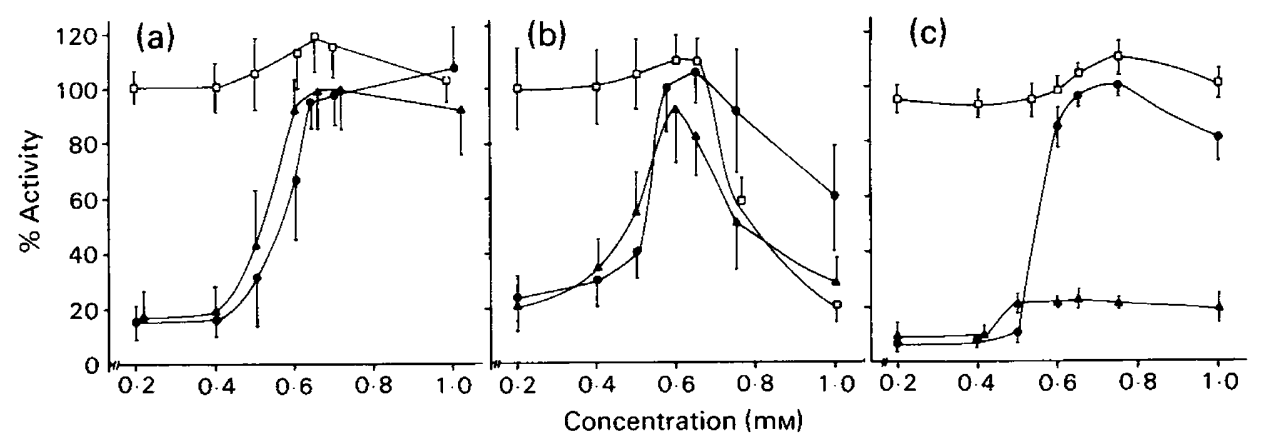

Text-fig. 5. Effect of various concentrations of (a) $\mathrm{Co}^{2+}$, (b) $\mathrm{Zn}^{2+}$ and (c) $\mathrm{Ni}^{2+}$ after a 90-min pretreatment with 0.75 mM-EDTA on the hydrolysis of CysNA and LeuNA by the enzyme preparations, cystine aminopeptidase $I_{m}(0)$, cystine aminopeptidase II ( $\square$ ) and arylamidase $I_{m}$ $(\Delta)$. The results of 5-6 duplicate experiments are given as percentages $( \pm$ s.e.m.) of the appropriate duplicate controls (100\%). 
had no effect. Cystine aminopeptidase II did not respond at all to $\mathrm{Ca}^{2+}, \mathrm{Co}^{2+}, \mathrm{Mg}^{2+}, \mathrm{Mn}^{2+}$ or $\mathrm{Ni}^{2+}$ but $\mathrm{Zn}^{2+}$ caused a marked inhibition of this enzyme at higher concentrations.

The effects of the various ions directly on the enzyme activities are shown in Table $3 . \mathrm{Ni}^{2+}$ had less inhibitory effect on cystine aminopeptidase II than on the other enzymes, but $\mathrm{Zn}^{2+}$ was a clear inhibitor of all of the enzymes. None of the other metal ions tested $\left(\mathrm{Ca}^{2+}, \mathrm{Co}^{2+}, \mathrm{Mg}^{2+}\right.$, $\mathrm{Mn}^{2+}$ ) had such an obvious effect on the enzyme activities and no other ions except $\mathrm{Ni}^{2+}$ produced significant differences between the enzyme responses.

Table 3. Effect of some divalent metal ions on the activity of arylamidase $I_{c}$ (LeuNA), cystine aminopeptidase $I_{m}$ and II (CysNA) and arylamidase $I_{m}$ (LeuNA) separated by gel filtration

\begin{tabular}{|c|c|c|c|c|c|}
\hline Ions & $\begin{array}{l}\text { Conc. } \\
\text { (mM) }\end{array}$ & LeuNA $I_{c}$ & CysNA $I_{m}$ & CysNA II & LeuNA I \\
\hline $\mathrm{Co}^{2+}$ & $\begin{array}{l}0.2 \\
0.6 \\
1.0\end{array}$ & $\begin{array}{l}103 \pm 5.4 \\
108 \pm 2 \cdot 0 \\
107 \pm 1.0\end{array}$ & $\begin{array}{r}93 \pm 8 \cdot 1 \\
81 \pm 19 \cdot 6 \\
100 \pm 16 \cdot 3\end{array}$ & $\begin{array}{r}104 \pm 6.4 \\
95 \pm 7.7 \\
94 \pm 11.0\end{array}$ & $\begin{array}{l}94 \pm 11.9 \\
86 \pm 8.5 \\
82 \pm 8.3\end{array}$ \\
\hline $\mathrm{Ni}^{2+}$ & $\begin{array}{l}0.2 \\
0.6 \\
1.0\end{array}$ & $\begin{array}{l}67 \pm 6 \cdot 1 \\
48 \pm 5 \cdot 1 \\
31 \pm 5.0\end{array}$ & $\begin{array}{l}85 \pm 4.9 \\
46 \pm 5.0 \\
29 \pm 4.6\end{array}$ & $\begin{array}{r}110 \pm 3.9^{*} \\
98 \pm 11.9^{+} \\
73 \pm 1.0^{+}\end{array}$ & $\begin{array}{l}53 \pm 7 \cdot 3 \\
19 \pm 4 \cdot 8 \\
14 \pm 2 \cdot 1\end{array}$ \\
\hline $\mathrm{Zn}^{2+}$ & $\begin{array}{l}0.2 \\
0.6 \\
1.0\end{array}$ & $\begin{array}{l}52 \pm 2.4 \\
25 \pm 7.2 \\
14 \pm 7.4\end{array}$ & $\begin{array}{l}58 \pm 25 \cdot 2 \\
28 \pm 13 \cdot 5 \\
16 \pm 7 \cdot 3\end{array}$ & $\begin{array}{l}35 \pm 7.1 \\
16 \pm 4.7 \\
16 \pm 5.3\end{array}$ & $\begin{array}{r}41 \pm 8.7 \\
14 \pm 4.6 \\
8 \pm 3 \cdot 1\end{array}$ \\
\hline
\end{tabular}

The values are mean \pm s.e.m. percentages of the hydrolysis rates obtained without added ions (100\% duplicate controls in every duplicate determination) for 3-6 duplicate experiments.

* Significantly different from the effect on the other enzymes at this concentration, $P<0.01$.

†ignificantly different from the effect on the other enzymes at this concentration, $P<0.001$.

The enzymes had also clear differences in their response to L-methionine (Text-fig. 6a). Cystine aminopeptidase II was not inhibited but cystine aminopeptidase $I_{m}$ and arylamidase $I_{m}$ did show gradual inhibition, and arylamidase $I_{c}$ was sensitive at every concentration.

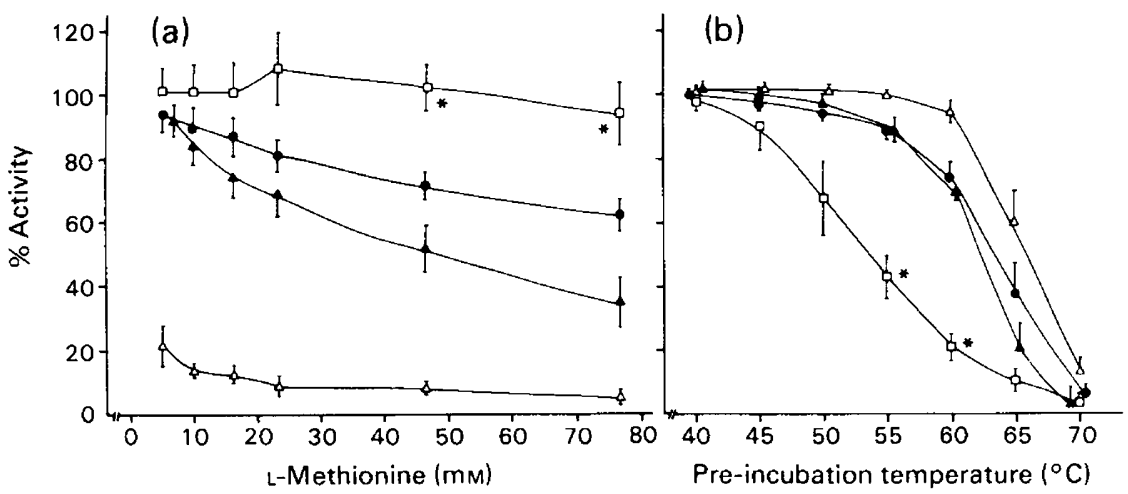

Text-fig. 6. Effect of (a) various L-methionine concentrations and (b) temperature on the hydrolysis of CysNA and LeuNA by the pooled enzyme preparations, cystine aminopeptidase $I_{m}(\bullet)$; cystine aminopeptidase II ( $\square)$; arylamidase $I_{m}(\Delta)$; arylamidase $I_{c}$ with LeuNA and CysNA as substrate $(\triangle)$. The results are given as percentages ( \pm s.e.m.) of the appropriate duplicate controls $(100 \%)$ for 5 duplicate experiments in (a) and of the uninhibited duplicate control values for 4 duplicate experiments in (b). Values marked with an asterisk are significantly different $(P<$ $0.005)$ from those of the other enzymes at that concentration and temperature. The arylamidase $I_{c}(\triangle)$ activities were significantly different $(P<0.001)$ from those of the other enzymes at all concentrations in (a) and at $60^{\circ} \mathrm{C}$ in (b). 
Arylamidase $I_{c}$ was the most resistant and cystine aminopeptidase II the most sensitive to thermal treatment (Text-fig. 6b).

Molecular weight. The fractionation on Sepharose 6B gave molecular weights of 130000 for arylamidase $I_{c}, 309000$ for enzyme activity $I_{m}$ with CysNA and LeuNA, and 76000 for cystine aminopeptidase II.

\section{Discussion}

In this study fractionation of human maternal serum by gel filtration showed that pregnancy caused the appearance of a new enzyme, which has cystine aminopeptidase (cystine aminopeptidase $I_{m}$ ) and arylamidase (arylamidase $I_{m}$ ) activity. The activities appeared to be identical with those previously characterized from human placenta (Lampelo \& Vanha-Perttula, 1979). This supports the previous conclusion that maternal serum cystine aminopeptidase (oxytocinase) is of placental origin (Oya et al., 1974; Small \& Watkins, 1975). The present study also showed that serum from non-pregnant women contains two aminopeptidases one of which hydrolysed L-leucine- $\beta$-naphthylamide (LeuNA) and weakly L-cystine-di- $\beta$-naphthylamide (CysNA) and the other only CysNA. Goebelsmann \& Beller (1965) isolated by Sephadex G200 gel filtration one arylamidase from control serum, and another enzyme, which was poorly separated from control serum arylamidase, from maternal serum. They reported that control serum arylamidase hydrolysed LeuNA 75 times faster than CysNA, and maternal serum cystine aminopeptidase was shown to hydrolyse LeuNA 11 times faster than CysNA. Goebelsmann \& Beller (1965) concluded that weak cystine aminopeptidase activity in control serum is due to arylamidase activity. Cystine aminopeptidase II, isolated from maternal and control serum in the present study, has not previously been detected.

Serum cystine aminopeptidase (oxytocinase) activities, measured by a bioassay, are approximately 13 times higher in pregnant than in non-pregnant women while arylamidase activities at term are 3.5 times higher (Tuppy \& Nesvadba, 1957; Goebelsmann \& Beller, 1965). Goebelsmann \& Beller (1965) suggested that the 3.5-fold increase in arylamidase activity is due to the appearance of cystine aminopeptidase, and the broad substrate specificity of the aminopeptidase produces pseudo-cystine aminopeptidase values in control serum. We found that both cystine aminopeptidase and arylamidase activities increased markedly during pregnancy, but the increase was higher with CysNA (12-5-fold) than with LeuNA (8-3-fold).

Ryden (1966) and Christensen (1974) determined the $\mathrm{pH}$ optimum for unfractionated control and maternal serum cystine aminopeptidase (oxytocinase). They used CysNA as substrate and demonstrated that the $\mathrm{pH}$ optimum increased during pregnancy. We found that the $\mathrm{pH}$ optima for maternal serum enzyme preparation I were higher than those for arylamidase $\mathrm{I}_{\mathrm{c}}$. Cystine aminopeptidase II had the same $\mathrm{pH}$ optimum in maternal and control serum. It is possible that the previously observed increase in $\mathrm{pH}$ optimum of cystine aminopeptidase is due to the new maternal serum enzyme(s) appearing only during pregnancy.

EDTA inhibits maternal serum cystine aminopeptidase (oxytocinase) (Werle \& Semm, 1956; Ryden, 1966) and control serum arylamidase (Fleisher, Pankow \& Warmka, 1964; McDonald, Reilly \& Ellis, 1964). In the present study EDTA strongly inhibited cystine aminopeptidase $I_{m}$, arylamidase $I_{m}$ and arylamidase $I_{c}$, even at very low concentrations. This could indicate that maternal and control serum Enzymes $I$ have a metal ion which is readily chelated in their active centre. However, the complete inhibition by EDTA required some time. Tuppy \& Wintersberger (1960) have demonstrated with serum oxytocinase that $20 \%$ inhibition occurred after $15 \mathrm{~min}$ and $90 \%$ after $120 \mathrm{~min}$ of preincubation with EDTA. The possibility that maternal serum cystine aminopeptidase (oxytocinase) is a metallo-enzyme (Melander, 1965) has not yet been confirmed.

Many investigators (Tuppy \& Wintersberger, 1960; Werle \& Semm, 1956; Mäkinen \& 
Raekallio, 1974) have studied the effect of divalent metal ions on maternal serum cystine aminopeptidase (oxytocinase) activity and observed activation, inhibition or no response in the enzyme activity. In the present study, maternal and control serum Enzymes I were more sensitive to $\mathrm{Ni}^{2+}$ than was cystine aminopeptidase II, whereas $\mathrm{Zn}^{2+}$ was inhibitory to all of these enzyme activities. Even though $\mathrm{Zn}^{2+}$ in itself was inhibitory, it, like $\mathrm{Co}^{2+}$, re-activated cystine aminopeptidase $I_{m}$, arylamidase $I_{m}$ and arylamidase $I_{c}$ after EDTA inhibition. Cystine aminopeptidase $I_{m}$ and arylamidase $I_{m}$ differed from each other in their response to $\mathrm{Ni}^{2+}$ after EDTA pretreatment and also had different $\mathrm{pH}$ optima. These observations do not prove that the coeluting CysNA- and LeuNA-hydrolysing activities of Peak $I_{m}$ represent different enzymes. The re-activation of arylamidase $I_{c}$ by $\mathrm{Ni}^{2+}$ when CysNA was used as substrate supports the previous studies by Vescia (1956) and Vanha-Perttula, Hopsu \& Glenner (1966), who have shown that an ion-determined specificity explains the different response obtained in the hydrolysis of the various amino acid naphthylamide substrates by a single aminopeptidase. Tiderström \& Heinegård (1978) have studied the hydrolysis of L-cystine-bis-4-nitroanilide, Lcystine-di- $\beta$-naphthylamide and $S$-benzyl-L-cysteine-4-nitroanilide by unfractionated pregnant serum cystine aminopeptidase. They showed that $\mathrm{Co}^{2+}$ activated the hydrolysis but the activation level was different with each of the substrates. Tiderström \& Heinegård (1978) suggested that the differences in the response to $\mathrm{Co}^{2+}$ were caused by the chemical and steric properties of each substrate used and were probably not due to different enzymes.

Cystine aminopeptidase II was resistant to EDTA, and its activity was not altered by divalent metal ions after EDTA treatment. However, the rate of hydrolysis by this enzyme was also decreased after EDTA treatment at low molarities of phosphate buffer. It has earlier been shown that serum cystine aminopeptidase activity during liver diseases is higher in Tris than in phosphate buffer (Tiderström \& Heinegård, 1978), while normal serum arylamidase activity is decreased (Fleisher et al., 1964). Because it is possible that serum aminopeptidases prefer different buffers and the buffer used influences enzyme characteristics, the buffer dependence should be taken into consideration in the characterization and quantitation of serum aminopeptidase activities.

Fleisher et al. (1964) showed that L-methionine inhibits competitively the control serum arylamidase. Oya et al. (1974) showed electrophoretically that the enzyme in control serum was inhibited by L-methionine $(0.02 \mathrm{M})$, whereas maternal serum enzyme bands $\left(\mathrm{CAP}_{1}, \mathrm{CAP}_{2}\right)$, representing two conformational forms of a single enzyme, were resistant to the treatment. This differential response has subsequently been suggested as being useful for estimating specifically the possible placental aminopeptidase activity in maternal serum (Mizutani, Yoshino \& Oya, 1976). The present study shows that cystine aminopeptidase $I_{m}$ and arylamidase $I_{m}$ were only partly inhibited by L-methionine. In contrast, L-methionine markedly inhibited arylamidase $I_{c}$ at every concentration. Oya et al. (1974) have shown that control serum arylamidase activity is heat-stable $\left(60^{\circ} \mathrm{C}, 30 \mathrm{~min}\right.$ ), whereas maternal serum cystine aminopeptidase (oxytocinase) can be inhibited by this treatment. Our finding of a clear difference between these enzymes at $60^{\circ} \mathrm{C}$ after 15 min preincubation confirms this. Cystine aminopeptidase II was not inhibited by Lmethionine, but it was sensitive to thermal treatment. Cystine aminopeptidase $I_{m}$, arylamidase $I_{c}$ and cystine aminopeptidase II therefore appear to be separate enzymes with different reactive sites.

In the present work cystine aminopeptidase $I_{m}$ and arylamidase $I_{m}$ had higher molecular weights (309 000) than control serum arylamidase (130 000). Yman \& Sjöholm (1967) estimated the molecular weight of oxytocinase purified from retroplacental serum as 325000 and Yman (1970) obtained a value of 290000 . Oya, Yoshino \& Mizutani (1975) estimated the molecular weight of the maternal serum enzyme as 320000 and that of the control serum enzyme as approximately 145000 .

In our previous study (Lampelo \& Vanha-Perttula, 1979) we characterized some biochemical properties of placental aminopeptidase activities hydrolysing CysNA and LeuNA co- 
eluting in the same fractions on gel filtration. The activities have similar biochemical characteristics to cystine aminopeptidase $I_{m}$ and arylamidase $I_{m}$. Based on these observations it is suggested that maternal serum cystine aminopeptidase $I_{m}$ is of placental origin and that it is perhaps the oxytocinase that is released into the maternal circulation during pregnancy. Serum cystine aminopeptidase II also had properties similar to those of placental cystine aminopeptidase II (Lampelo \& Vanha-Perttula, 1979), and this enzyme appears to be distinct from any of the previously characterized serum aminopeptidases. Since maternal and control sera contain this cystine aminopeptidase activity which hydrolyses CysNA, a synthetic substrate for oxytocinase, further studies are necessary to explore its tissue origin and physiological function in serum. It should also be taken into consideration during development of a specific method for oxytocinase for monitoring the placental functions.

This study has been supported by grants from The Sigrid Jusélius Foundation, Helsinki, Finland and from The Research and Science Foundation of Lääke Oy, Turku, Finland.

\section{References}

Babuna, C. \& Yenen, E. (1966) Enzymatic determination of placental function. A rapid method. $A m$. $J$. Obstet. Gynec. 95, 925-934.

Christensen, A. (1974) Hormone and enzyme assays in pregnancy. I. Studies on the placental and the tissue cystine-aminopeptidase activity in peripheral plasma from non-pregnant and pregnant women and in plasma from umbilical cord. Acta endocr., Copenh. 76, 189-200.

Fleisher, G.A., Pankow, M. \& Warmka, C. (1964) Leucine aminopeptidase in human serum: Comparison of hydrolysis of L-leucylglycine and Lleucyl- $\beta$-naphthylamide. Clin. chim. Acta 9, 259268.

Gazarek, F., Pohanka, J., Talas, M., Fingerova, H., Janouskova, M., Krikal, Z. \& Hamal, Z. (1976) Plasma oxytocin and oxytocinase levels in third trimester of pregnancy and at labour. Endocr. exp. 10, $283-287$.

Goebelsmann, U. \& Beller, F.K. (1965) Separation of cystine-amino-peptidase and leucine-amino-peptidase and their determination in pregnant and nonpregnant women. $Z$. klin. Chem. 3, 49-54.

Kulling, B. \& Yman, L. (1970) Purification and some properties of leucine aminopeptidases from retroplacental serum. Acta pharm. suecica 7, 65-74.

Lampelo, S. \& Vanha-Perttula, T. (1979) Fractionation and characterization of cystine aminopeptidases (oxytocinase) and arylamidase of the human placenta. J. Reprod. Fert. 56, 285-296.

Lowry, O.H., Rosebrough, N.J., Farr, A.L. \& Randall, R.J. (1951) Protein measurement with the Folin phenol reagent. J. biol. Chem. 193, 265-275.

Mäkinen, P.-L. \& Raekallio, J. (1974) Aminopeptidases in the serum of pregnant and nonpregnant women. Biochem. Med. 11, 210-216.

McDonald, J.K., Reilly, T.J. \& Ellis, S. (1964) The hydrolysis of amino acyl- $\beta$-naphthylamides by plasma aminopeptidases. Biochem. Biophys. Res. Commun. 16, 135-140.

Melander, S. (1965) Plasma oxytocinase activity. A methological and clinical study with special reference to pregnancy. Acta endocr., Copenh. 48, Suppl. 96, 1-94.

Mizutani, S., Yoshino, M. \& Oya, M. (1976) A comparison of oxytocinase and L-methionineinsensitive leucine aminopeptidase during normal pregnancy. Clin. Biochem. 9, 228.

Oya, M., Yoshino, M., Mizutani, S. \& Wakabayashi, T. (1974) The origin of human pregnancy serum oxytocinase. Gynecol. Invest. 5, 276-283.

Oya, M., Yoshino, M. \& Mizutani, S. (1975) Molecular heterogeneity of human placental aminopeptidase isozymes. Experientia 31, 1019-1020.

Ryden, G. (1966) Cystine aminopeptidase and oxytocinase activity in pregnancy. A comparative study in human and rat tissue. Acta obstet. gynec. scand. 45, Suppl. 3, 1-105.

Small, C.W. \& Watkins, W.B. (1975) Oxytocinaseimmunohistochemical demonstration in the immature and term human placenta. Cell Tissue Res. 162, 531-539.

Spellacy, W.N., Usategui-Gomez, M. \& FernandezdeCastro, A. (1977) Plasma human placental lactogen oxytocinase, and placental phosphatase in normal and toxemic pregnancies. Am. J. Obstet. Gynec. 127, 10-16.

Stoklaska, E. \& Wintersberger, E. (1959) Zum Mechanismus des Oxytocin- und Vasopressin-Abbaues durch Schwangerenserum. Arch. exp. Path. Pharmak. 236, 358-364.

Tiderström, G. \& Heinegärd, D. (1978) Determination of cystyl-aminopeptidase. Isoenzymes in seminal plasma and serum of different origin. Clin. chim. Acta 88, 293-304.

Tuppy, H. \& Nesvadba, H. (1957) Über die Aminopeptidaseaktivität des Schwangerenserums und ihre Beziehung $z u$ dessen Vermögen, Oxytocin zu inaktivieren. Mh. Chem. 88, 977-988.

Tuppy, H. \& Wintersberger, E. (1960) Reinigung und Eigenschaften der Serum-Oxytocinase. Mh. Chem. 91, 1001-1010. 
Vanha-Perttula, T, Hopsu, V.K. \& Glenner, G.G. (1966) Enzymes in hog kidney hydrolyzing amino acid naphthylamides. J. Histochem. Cytochem. 14, 314325.

Vescia, A. (1956) Ion-determined specificity of peptidase activity. Biochim. Biophys. Acta 19, 174-175.

von Fekete, K. (1930) Beiträge zur Physiologie der Gravidität. Endokrinologie 7, 364-369.

Werle, E. \& Semm, K. (1956) Über die Oxytocinase des Schwangerenblutes. Arch. Gynaek. 187, 449-457.
Whitaker, J.R. (1963) Determination of molecular weights of proteins by gel filtration on Sephadex. Analyt. Chem. 35, 1950-1953.

Yman, L. (1970) Composition of oxytocinase (cystine aminopeptidase). Acta pharm. suecica 7, 29-36.

Yman, L. \& Sjöholm, I. (1967) Some physicochemical properties of oxytocinase (cystine aminopeptidase). Acta pharm. suecica 4, 13-22.

Received 15 May 1979 